\title{
The Use of Modern Teaching Methods in College English under the New Media Environment
}

\author{
Y. ZHU \& J. WANG \\ School of Foreign Language, Wuhan Bioengineering Institute, Hubei, China
}

\begin{abstract}
In teaching activities, in addition to suitable teaching strategies, the use of teaching methods also has a significant impact on students' learning. The effective use of modern teaching methods can play a multiplier effect on teachers' teaching. Therefore in the teaching process, teachers should be familiar with effective teaching methods to improve students' learning efficiency. This article dwells on the use of modern teaching methods in College English under the new media environment.
\end{abstract}

KEYWORDS: New media; Teaching Methods; College English Teaching

\section{INTRODUCTION}

The development of English teaching methods has gone through four stages from the initial phase of language laboratories, computer-aided teaching to the present Internet age.

Since the mid-1990s, with extensive use of computers and the popularity of the Internet, we have entered a new era--the era of WELL (Webenhanced language learning). Multimedia-assisted teaching provides not only the true language teaching situations, but also the interaction and exchanges between human and computer, teachers and students. With the use of the Internet and emails, teachers and students have carried out more extensive exchange activities in real thoughts and language, which plays an important role for the full cultivation of students' foreign language abilities.

\section{COLLEGE ENGLISH TEACHING IN MODERN NETWORK STAGE}

Foreign language teaching attaches great importance to the Internet, calling it the most diverse media and representing a revolution in human history. Here are some important issues shows the superiority of the Internet teaching in foreign language teaching.

\subsection{Providing a large number of real, authentic and vivid language}

It has always believed that students must learn the true, authentic foreign languages. In the period dominated by Grammar Translation Method, most students learned the language through literature. Although they learned foreign language from the classics and improved the training of foreign literature, they often felt strange to the language actually used in daily communication. In the period dominated by Audiolingual Method, learners learnt foreign language from the textbooks and rewritten simple books based on the structure of written language, which was accused of not being authentic by Communicative Approach advocators. Foreign languages on the Internet (mainly English) contain both literary language and a lot of slangs used in daily life by native speakers. Its vividness and large quantities are unmatched by any textbook.

\subsection{Creating $a$ rich and varied language and cultural resources}

Foreign language teaching advocates the contact with a large number of language materials to promote cultural knowledge. However, the lack of teaching resources always makes foreign language teachers confused. Internet has provided a large variety of subjects with various levels of materials more than any rich content library. Global Networking enables teachers and students to have access to millions of books, newspapers and files, and teachers and students can exchange ideas rapidly around the world, so that the classroom extends. At the same time, due to the constantly updated information on the network, teachers and students can be access to the latest information timely, and be aware of the changes and development of language. 


\subsection{Promoting the language skills, cognition, and communicative competence}

Synchronous or asynchronous communication with the others with the help of the network via e-mails, Chat-Rooms, Video-Conferencing, etc. enables teachers and students to carry out varied communicative activities, which is good for information exchange, the improvement of the students' overall level of speaking and writing, and developing students' cognitive and communicative competence.

\subsection{Cultivating the spirit and ability of autonomous learning}

Under the guidance of teachers, it is very conducive for students to learn a foreign language online to improve the spirit and the ability of autonomous learning. The environment of foreign language learning is far less favorable than native language learning environment; therefore, cultivating the ability of autonomous learning is not an easy thing in foreign language teaching. With the network instruction, each student is required to use a foreign language to query information to choose needed materials, and exchange information with teachers or classmates. The phenomenon that relying on teachers or other students in traditional foreign language classroom is difficult to continue to exist. That is very conducive to train students' autonomous learning ability.

\section{THE USE OF MODERN ENGLISH TEACHING METHODS IN THE LISTENING AND SPEAKING COURSE}

"Listening" is one of the main ways to absorb information, and its combination with "speaking" is an important means of communication. In actual use of language, listening and speaking often closely linked. Still, listening and speaking, are two different skills, their teaching methods still have the different characteristics. Recently, especially since the linguist Krashen proposed the importance of comprehensible input, the researches related to listening teaching theories and methods are constantly updated. How to effectively improve speaking capability has been a focus of attention of all schools, and modern foreign language teaching techniques are very diverse. The following is a few key aspects of modern teaching techniques.

\subsection{The use of a variety of modern teaching methods to increase comprehensible language input}

Krashen stressed in his Input Hypothesis that only when learners understand the inputed language could language acquisition and learning follow the natural order. Comprehensible language input has at least three meanings: First, there must be a certain amount; second, it should maintain a high quality of pure and authentic language input; third, it should be understood by learners. That means the difficulty of the language input should be suitable for and slightly higher than the levels of learners, reaching the socalled "i (learner current levels) +1 " requirements.

To enable students to learn a lot comprehensible language input, using a variety of teaching methods is needed. With increasing demands with students' foreign language proficiency and the rapidly growing desire and ability to absorb the knowledge of a foreign language inside and outside of the class, just relying on a small number of audio and video or a limited number of passive listening in the language lab in traditional English classroom is clearly not enough. The good news here is that the modern teaching techniques have made a lot of progress in the following aspects.

\subsubsection{Increasing the students' comprehensive language input by using the new media}

Multimedia is one of the teaching methods combining picture, graph, image, animation, sound, music and text. It contains a variety of forms, and can be used alternately or simultaneously. Therefore, within the same time, the use of multimedia is much greater in providing language input quantities. On language quality, multimedia can combine multiple languages with each other, and thus it can express the meaning of language more accurately. More importantly, it can deepen students' understanding of language and help memorizing on the basis of understanding. According to statistics, in general, memory content of the adult brain can be $25 \%$ via the auditory language material, $45 \%$ through visual language materials, $70 \%$ through the auditory, visual and practicing remembering. Therefore, in terms of quantity, quality or intelligibility of language input, these advantages of multimedia teaching methods are superior.

\subsubsection{Providing language input by using a variety of computer software}

Currently, there are a variety of software that can assist listening and speaking teaching. For example, selecting some stories or reports related to the text content and using them as a warm-up before the class to provide background materials to assist understanding of the text and increase the language input. Another example is choosing some stories related with the vocabulary of the text from software dealing with the meaning and usage of English vocabulary. Students click on these words with lively illustrations. In that way, you can hear a lot of stories or description while increasing the language 
input with further understanding the meaning of a single word. Also, the use of these software is controlled by the students. It can be repeated many times to listen to, which is very beneficial to improve the ability to understand a foreign language.

\subsubsection{Selecting suitable materials for students by using the material provided by the Internet}

Today, with extremely rich content on the web, teachers can download a variety of materials available to students from some foreign language website in order to increase their language input. For example: The English Listening Lounge (http://www.englishlistening.com/) and English Listening Room (http://www.manythings.org/pp/) are all good websites.

\subsection{The use of multimedia to create language scenarios for students}

Different from the aims to increase the language input, using multimedia to create language scenarios concerns the learning of the background knowledge of the context; while the former pays attention to the main language content from the quantity and quality considerations with respect to the degree of intelligibility. At the same time, when creating scenarios by using multimedia, we need to examine whether it matches the required social and cultural phenomenon of the target foreign language.

\section{CONCLUSION}

Network teaching has so much vitality not only because it has the above advantages, but it is rooted in cognitive psychology and sociolinguistics soil. The purpose of the network teaching is to enable students to understand the meaning of the language, to develop analytical and judging ability, and to improve the communicative competence in interpersonal communication. Therefore, some applied linguists believe that its theoretical basis is a combination of cognitive theory and sociolinguistics.
It is the theory that makes the role of computers changed in language teaching: it developed from an early stage of providing language practice based on the theory of structuralism linguistics into tools to improve the cognitive level of communicative language competence. Therefore, the SLT based on the network is not only the consequence of the progress of science and technology in the information age, but also the product of the combination of cognitive psychology and sociolinguistics. Computer technology is an advanced means. Cognitive psychology and sociolinguistics are embodiment of the concept of scientific language. A combination of both gives online teaching a strong vitality and promotes the development of foreign language teaching in the new century.

\section{ACKNOWLEDGEMENT}

This paper is part of the fruit of the Provincial Teaching Research Projects of Hubei province. (No. 2014405)

\section{REFERENCES}

[1] Ahmad, J. 2012. English Language Teaching (ELT) and Integration of Media Technology. Procedia - Social and Behavioral Sciences. 47: 924-929

[2] Chen, Y.C. 2014. An empirical examination of factors affecting college students' proactive stickiness with a web-based English learningenvironment. Computers in Human Behavior. 31:159-171

[3] Ghasemi, B. \& Hashemi, M. 2011. ICT: Newwave in English language learning/teaching. Procedia - Social and Behavioral Sciences. 15: 3098-3102

[4] Lee, H.C. 2014. Social media and student learning behavior: Plugging into mainstream music offers dynamic ways to learn English. Computers in Human Behavior. 36:496-501

[5] Yang, Y.T. 2013. A blended learning environment for individualized English listening and speaking integrating critical thinking. Computers \& Education. 63: 285-305 